\title{
GEOCHEMICAL PECULIARITIES OF SOILS IN TOMSK AREAS OF INDUSTRIAL ENTERPRISES LOCATIONS L.V. Zhornyak ${ }^{a}$, N.A. Osipova ${ }^{a}$, E. G. Yazikov ${ }^{a}$, K. E. Demidova ${ }^{a}$, K. Yu. Osipov \\ ${ }^{a}$ National Research Tomsk Polytechnic University, 634050 Tomsk, Russia; ${ }^{b}$ V.E. Institute of Atmospheric Optics SB RAS, 1 Academician Zuev square, Tomsk, Russia, 634021
}

\begin{abstract}
The study of soil samples taken in regions of the industrial enterprises locations in Tomsk areas was performed. The instrumental neutron-activation analysis was used for determination of the chemical composition of samples. The accumulation levels of 26 chemical elements in soils, including rare and radioactive, were determined. The level values of all of the studied elements exceeded background concentrations. The observed elements concentrations exceeded the background ones by factor ranging from 1.1 for $\mathrm{Rb}$ (Artificial stone plant) up to $20 \mathrm{for} \mathrm{Br}$ (Borrow pit enterprise) to 28 for Ce (Ash dump of the heat power station). The pollution of all studied areas was estimated as high on the basis of calculated values of the total pollution index. The soil geochemical peculiarities in Tomsk are established by elements accompanying production in regions of industrial enterprises locations. The soil composition reflects the specificity of the urban area with various industrial enterprises, due to certain properties of the soil, which constantly accumulates pollutants of emissions from businesses shops and vehicles.
\end{abstract}

Key words: urban soils, industrial enterprises, geochemical characteristics, concentration ratio, total pollution index

\section{INTRODUCTION}

The soil as one of the main components of the natural environment is constantly under negative impacts. Urban soils act as a mechanical barrier to aerogenic flows of man-made substances and are the long-term repository medium. The process of long-term contamination of urban soils causes changings in their chemical composition and acid-base characteristics [1]. The feature of urban soils pollution resides in the fact that a large number of different pollution sources (industrial enterprises, transport, placement, waste, etc.) are located on relatively small areas. The diversified industry and application of various technologies lead to accumulation in urban soils not only of the so-called "priority" elements $(\mathrm{Zn}, \mathrm{Cd}, \mathrm{Pb}, \mathrm{Cu})$, which usually studied, but also a large number of others [2-8].

The soil cover in the city of Tomsk is constantly exposed to both natural (water and wind erosion, waterlogging) and anthropogenic factors (chemical pollution, compaction, destruction and disposal of soils during construction, etc.). The most intense anthropogenic impact is manifested in the city areas of the industrial enterprises locations. This causes the intensity and heterogeneity of soil contamination, therefore, evaluation of the ecological-geochemical conditions of urban soils is necessary. According to the results of the areal research conducted lately in the areas of the city, the local geochemical anomalies in the percentage of some elements in soils are attributed to different industrial enterprises, and they are likely associated with the specific characters of their activities (Fig. 1). For example, the elevated relative average content of $\mathrm{Br}$ for the whole sampling is detected in the area of Chemical-Pharmaceutical Plant, Instrument and Lamp factories, $\mathrm{Co}$ - Tool plant, $\mathrm{Sb}$ - Sleeper impregnation plant, $\mathrm{Ce}$ - in the area of the coal storage of the Tomsk heat power station; $\mathrm{Hf}, \mathrm{Sm}, \mathrm{Eu}, \mathrm{La}, \mathrm{Ce}, \mathrm{Yb}$ and $\mathrm{Lu}$ - Concrete Plants $[2,9]$ It should be noted that the concentrations of elements in samples of urban soils in residential blocks close to industrial premises exceed the background values by the factor of $1.1-48$. Elevated contents halos of $\mathrm{Cs}, \mathrm{Sr}, \mathrm{Sc}, \mathrm{La}, \mathrm{Ce}, \mathrm{Yb}$ and $\mathrm{Lu}$ in the soils are detected in the ash disposal area of the Tomsk power station in the floodplain of the river Ushayka; $\mathrm{Cr}, \mathrm{Rb}, \mathrm{Sr}, \mathrm{Tb}, \mathrm{Sm}, \mathrm{Eu}, \mathrm{La}, \mathrm{Ce}, \mathrm{Yb}$ and Lu - at the end of Michurin street near the premises of Matches factory, but this may be associated with the activities of various smaller factories and repair shops; $\mathrm{Rb}, \mathrm{Cs}, \mathrm{Tb}, \mathrm{La}, \mathrm{Yb}$ and $\mathrm{Lu}$ in the RAS campus, due to the various scientific laboratories and the raised relief of the territory [2]. In connection with this, it was appropriate to conduct more detailed testing of these areas to redetermine the previously detected anomalies. In addition, it was necessary to expand the boundaries of research and obtain new data.

22nd International Symposium Atmospheric and Ocean Optics: Atmospheric Physics, edited by

Gennadii G. Matvienko, Oleg A. Romanovskii, Proc. of SPIE Vol. 10035, 100354H

(C) 2016 SPIE · CCC code: $0277-786 X / 16 / \$ 18 \cdot$ doi: $10.1117 / 12.2249317$

Proc. of SPIE Vol. $10035100354 \mathrm{H}-1$ 

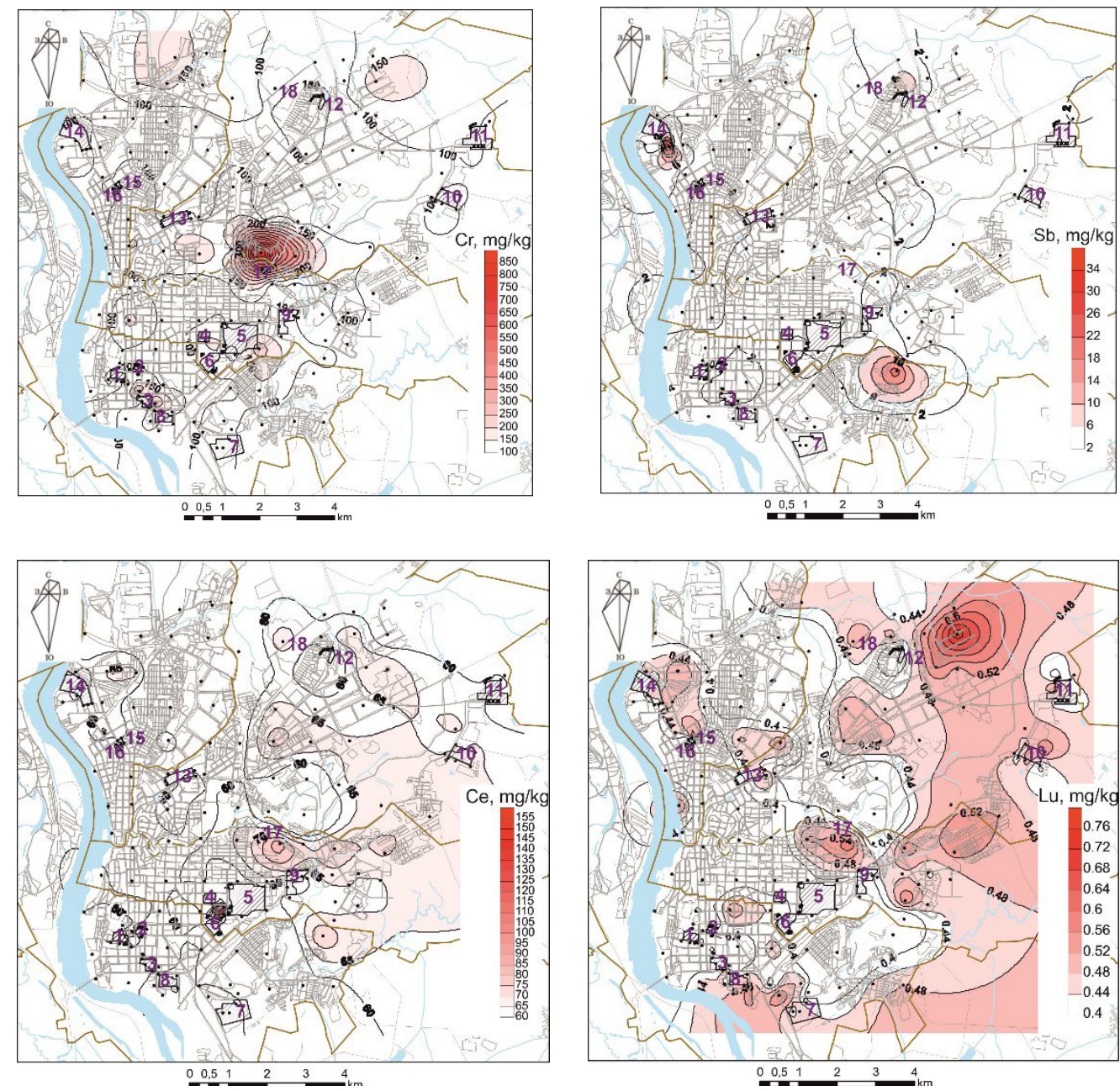

Fig. 1. Diagrams of surface distribution of various elements contents in soils of Tomsk area

1 - Electromechanical plant; 2 -Lamp factory; 3 - Tool plant; 4 - Manometry plant; 5 - Heat power station; 6 - Factory of electric motors; 7-Radio engineering plant ; 8 - Building company; 9 - Enamel production; 10 - Immune-biological medicines production; 11 - Instrument factory; 12 -Match factory; 13 -Cable production; 14 -Sleeper impregnation plant; 15 -Chemical-Pharmaceutical plant; 16 - Yeast plant ; 17 -Ash dump of heat power station ; 18 - Concrete plants

\section{EXPERIMENTAL PART}

The study is based on the test of 32 samples of urban soils picked up in early summer of 2013, at the surface layer $(0-10 \mathrm{~cm})$ in areas of operating industrial enterprises of power, construction and petrochemical production (Fig. 2). In addition, samples were picked up at soils of conditionally background areas (the village Pobeda), located $40 \mathrm{~km}$ from the Tomsk city. Treatment of samples meant for analytical investigations was done according to the standard scheme.

The quantitative determination of 26 elements by the instrumental neutron activation analysis in the credentialed nuclear-geochemical laboratory of the Department of Geoecology and Geochemistry, functioning on the basis of nuclear research reactor (analysts senior researchers A.F. Sudyko, L. V. Bogutskaya) was carried out. At this the internal control of the parallel definitions of the elements was provided. The determination inaccuracy for the majority of the analyzed elements did not exceed $10-15 \%$. 


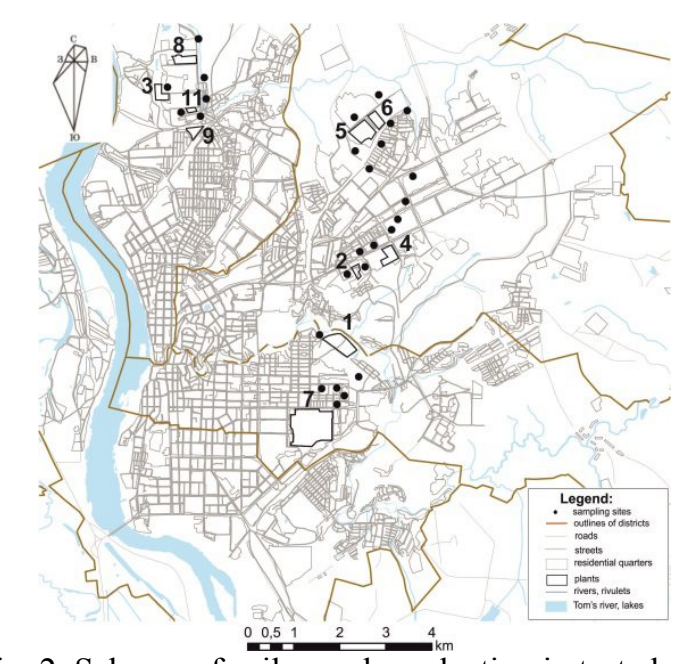

Fig. 2. Scheme of soil samples selection in tested areas:

1 - Ash dump of heat power station; 2 - Borrow pit enterprise; 3 - Concrete products plant; 4 - Construction materials plant; 5 - Concrete components plant-100; 6 - Concrete components plant-40; 7 - Heat power station; 8 Cement plant; 9 - Concrete plant; 11 - Artificial stone plant.

\section{RESULTS AND DISCUSSION}

The table shows the concentrations ratios of chemical elements in soils in the areas close to industrial enterprises calculated with regard to the background (Villige Pobeda) and the values of total pollution index (TPI).

Table

Ratios of concentrations of chemical elements in soils in the areas close to industrial facilities in Tomsk calculated with regard to the background (Villige Pobeda), and the values of total pollution index (TPI).

\begin{tabular}{|c|c|c|}
\hline Area & Ratio of concentration & TPI, unic \\
\hline Heat power station & 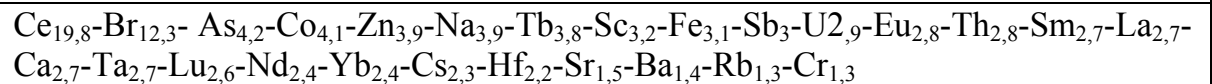 & 73 \\
\hline $\begin{array}{l}\text { Ash d } \\
\text { power }\end{array}$ & 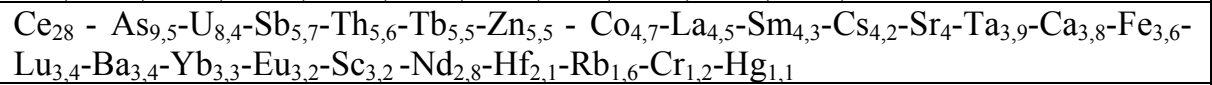 & 102 \\
\hline $\begin{array}{l}\text { Borrow pit } \\
\text { enterprise }\end{array}$ & 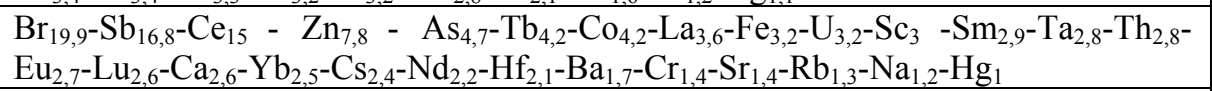 & 93 \\
\hline $\begin{array}{l}\text { Construction } \\
\text { materials plant }\end{array}$ & 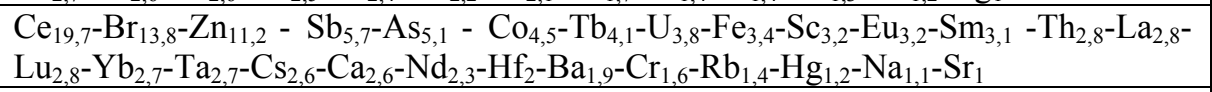 & 86 \\
\hline Cement plant & $\begin{array}{l}\mathrm{Ce}_{15,8}-\mathrm{Zn}_{8,6}-\mathrm{Br}_{7,7}-\mathrm{Sb}_{5,8}-\mathrm{As}_{4,7}-\mathrm{Co}_{3,4}-\mathrm{Tb}_{3,2}-\mathrm{Ca}_{2,9}-\mathrm{U}_{2,9}-\mathrm{Fe}_{2,9}-\mathrm{Hg}_{2,6}-\mathrm{Sc}_{2,4}-\mathrm{Sm}_{2,3}-\mathrm{Lu}_{2,2^{-}} \\
\mathrm{Yb}_{2,2^{-}}-\mathrm{Ta}_{2,2}-\mathrm{Th}_{2,1}-\mathrm{La}_{2,1}-\mathrm{Nd}_{2}-\mathrm{Eu}_{1,9}-\mathrm{Hf}_{1,9}-\mathrm{Ba}_{1,7}-\mathrm{Cr}_{1,7}-\mathrm{Cs}_{1,6}-\mathrm{Sr}_{1,4}-\mathrm{Na}_{1,4}-\mathrm{Rb}_{1,2}\end{array}$ & 65 \\
\hline $\begin{array}{l}\text { Concrete products } \\
\text { plant }\end{array}$ & 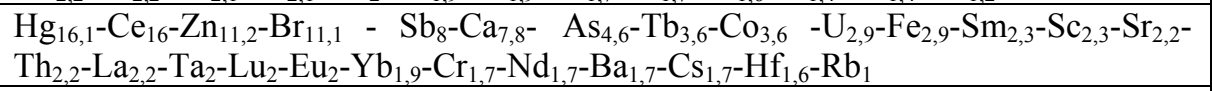 & 91 \\
\hline $\begin{array}{l}\text { Artificial stone } \\
\text { plant }\end{array}$ & 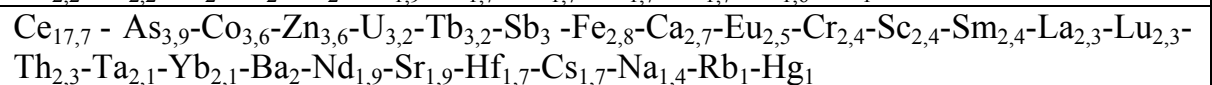 & 52 \\
\hline Concrete plant & 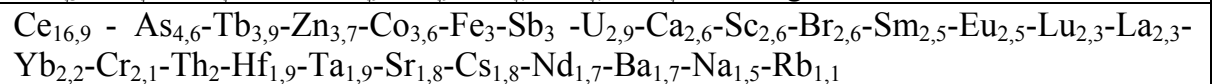 & 54 \\
\hline $\begin{array}{l}\text { Concrete } \\
\text { components plant- } \\
100\end{array}$ & $\begin{array}{l}\mathrm{Ce}_{23,6}-\mathrm{Br}_{15,5}-\mathrm{Zn}_{6,5}-\mathrm{As}_{5,7}-\mathrm{Tb}_{4,6}-\mathrm{Sb}_{4,3}-\mathrm{Co}_{4,1_{1}}-\mathrm{U}_{3,6^{-}}-\mathrm{Ca}_{3,2}-\mathrm{Fe}_{3,1}-\mathrm{Sc}_{3}-\mathrm{Sm}_{3}-\mathrm{Ta}_{3}-\mathrm{La}_{2,9^{-}}-\mathrm{Lu}_{2,8^{-}} \\
\mathrm{Th}_{2,7^{-}}-\mathrm{Eu}_{2,6^{-}} \mathrm{Yb}_{2,6^{-}}-\mathrm{Hf}_{2,4^{-}}-\mathrm{Nd}_{2,3}-\mathrm{Cs}_{2,2}-\mathrm{Ba}_{1,8^{-}}-\mathrm{Cr}_{1,3}-\mathrm{Sr}_{1,3}-\mathrm{Na}_{1,3}-\mathrm{Rb}_{1,3}-\mathrm{Hg}_{1,2}\end{array}$ & 86 \\
\hline $\begin{array}{l}\text { Concrete } \\
\text { components plant - } \\
40\end{array}$ & $\begin{array}{l}\mathrm{Ce}_{20,2}-\mathrm{Sb}_{10,8}-\mathrm{Tb}_{5,3}-\mathrm{Zn}_{5,3}-\mathrm{As}_{4,9} \mathrm{Co}_{4,2}-\mathrm{Fe}_{3,3}-\mathrm{Sc}_{3,3}-\mathrm{Sm}_{3}-\mathrm{Ta}_{3}-\mathrm{La}_{2,9}-\mathrm{Lu}_{2,9}-\mathrm{Eu}_{2,9^{-}} \mathrm{Th}_{2,8^{-}} \\
\mathrm{Yb}_{2,7^{-}} \mathrm{Ca}_{2,5}-\mathrm{Hf}_{2,5^{-}}-\mathrm{U}_{2,4^{-}}-\mathrm{Cs}_{2,4}-\mathrm{Nd}_{2,3}-\mathrm{Br}_{1,9}-\mathrm{Sr}_{1,7}-\mathrm{Ba}_{1,6}-\mathrm{Cr}_{1,5}-\mathrm{Na}_{1,5}-\mathrm{Rb}_{1,4}-\mathrm{Hg}_{1,3}\end{array}$ & 74 \\
\hline Petrochemical plant & $\begin{array}{r}\mathrm{Ce}_{17,7}-\mathrm{Sb}_{5,8}-\mathrm{As}_{3,9}-\mathrm{Tb}_{3,6}-\mathrm{Co}_{3,3}-\mathrm{Br}_{3}-\mathrm{Zn}_{2,9}-\mathrm{U}_{2,7}-\mathrm{Fe}_{2,7}-\mathrm{Sc}_{2,6}-\mathrm{Sm}_{2,4}-\mathrm{Eu}_{2,3}-\mathrm{La}_{2,2^{-}} \\
\mathrm{Lu}_{2,2}-\mathrm{Yb}_{2,1}-\mathrm{Ca}_{2,1}-\mathrm{Th}_{2,1}-\mathrm{Ta}_{2}-\mathrm{Cs}_{1,9}-\mathrm{Nd}_{1,8}-\mathrm{Hf}_{1,8}-\mathrm{Sr}_{1,-}-\mathrm{Cr}_{1,4}-\mathrm{Ba}_{1,3}-\mathrm{Na}_{1,2}-\mathrm{Rb}_{1,1}\end{array}$ & 52 \\
\hline
\end{tabular}


The results of urban soils studies gave the levels of accumulation of rare, including rare earth and radioactive, elements. With relation to background concentrations the accumulation of all studied elements is observed. The minimum excess over the background is 1.1 times for the $\mathrm{Rb}$ (Artificial stone plant), the maximum is up to 20 times for $\mathrm{Br}$ (Borrow pit enterprise) and 28 times for $\mathrm{Ce}$ (ash pond of Tomsk heat power station). Above the regular maximum permissible concentrations for soils the contents of $\mathrm{Zn}, \mathrm{Co}$ and As were detected in all studied samples. The percentage abundance in the Earth crust [10] in the samples of urban soils (for total sampling) was noted for the following elements: $\mathrm{Cr}, \mathrm{Sb}, \mathrm{As}$, Hf. In addition, the average content of the elements $\mathrm{Na}, \mathrm{Br}, \mathrm{Nd}$ above percentage abundance values in soils were found in the area of the Heat Power Station, $\mathrm{Zn}, \mathrm{Br}, \mathrm{Cs}, \mathrm{Nd}$ - Borrow Pit Enterprise, $\mathrm{Br}$, $\mathrm{Ba}, \mathrm{Zn}, \mathrm{Cs}, \mathrm{Nd}, \mathrm{U}$ - Construction materials plant ; Br, Zn, Hg - cement plant; Br, Zn, Hg - Concrete products plant; $\mathrm{Ba}$ Artificial stone plant; $\mathrm{Br}$ - Concrete Plant; $\mathrm{Br}, \mathrm{Zn}, \mathrm{Ce}, \mathrm{Nd}$ - Concrete components plant 100; $\mathrm{Br}, \mathrm{Zn}, \mathrm{Tb}, \mathrm{Nd}$ - Concrete components plant 40; Br - Petrochemical plant; $\mathrm{Ba}, \mathrm{Zn}, \mathrm{Cr}, \mathrm{Sb}, \mathrm{As}, \mathrm{Cs}, \mathrm{Hf}, \mathrm{Tb}, \mathrm{La}, \mathrm{Nd}, \mathrm{Yb}, \mathrm{U}$, Th - The ash dump of the Tomsk Power Station.

The territory of the ash dump, if compared to average values in sampling, showed high contents of most of the studied elements (Ba, Co, As, Rb, Cs, Sr, Ta, Tb, Sm, Eu, La, Ce, Nd, Yb, Lu, U, Th). According to previous studies in the area of the ash dump in the floodplain of the river Ushayka the elevated concentrations of $\mathrm{U}, \mathrm{Cs}, \mathrm{Sr}, \mathrm{Sc}, \mathrm{La}, \mathrm{Ce}, \mathrm{Yb}$, $\mathrm{Lu}$ and the increased value of the exposure dose $[2,11]$ were also noted.

In the soils around Heat power station in the higher concentration of $\mathrm{Br}, \mathrm{Ce}, \mathrm{As}, \mathrm{Sr}, \mathrm{Na}$, compared with other enterprises data and average city concentrations were observed. It is known that coal, as a natural formation, used as fuel at Tomsk heat power station contains rare, including rare earth and radioactive, elements, in addition to heavy metals so it's incineration causes the increase of element's concentration in the ash of ablation $[12,13]$. These elements within the sanitary protection zone of the enterprise showed lower concentrations and that can be explained by the transfer of emissions from tall stacks of Tomsk power station at long range. This is confirmed by the studies of the peculiarities of the composition of solid snow residues: concentration of rare, including rare-earth, elements increased by 2 times with distance from the power station $[14,15]$. In the area of Borrow Pit Enterprise elevated concentrations of $\mathrm{Ce}, \mathrm{Br}, \mathrm{Sb}$ with regard to background ones are noted; Construction materials plant $-\mathrm{Fe}, \mathrm{Br}, \mathrm{Zn}, \mathrm{Sc}, \mathrm{Eu}, \mathrm{Ce}$; Concrete products plant $\mathrm{Zn}, \mathrm{Cr}$, Sr. High concentrations of $\mathrm{Hf}, \mathrm{La}, \mathrm{Ce}, \mathrm{Eu}, \mathrm{Yb}$ and Ta were also previously recorded in the dust emissions of construction industry [15].

According to the value of the total index of soil contamination by different elements (table, Fig. 3) and its adopted gradation, the degree of pollution is high and that might correspond to the high level of population morbidity (projected) [18].

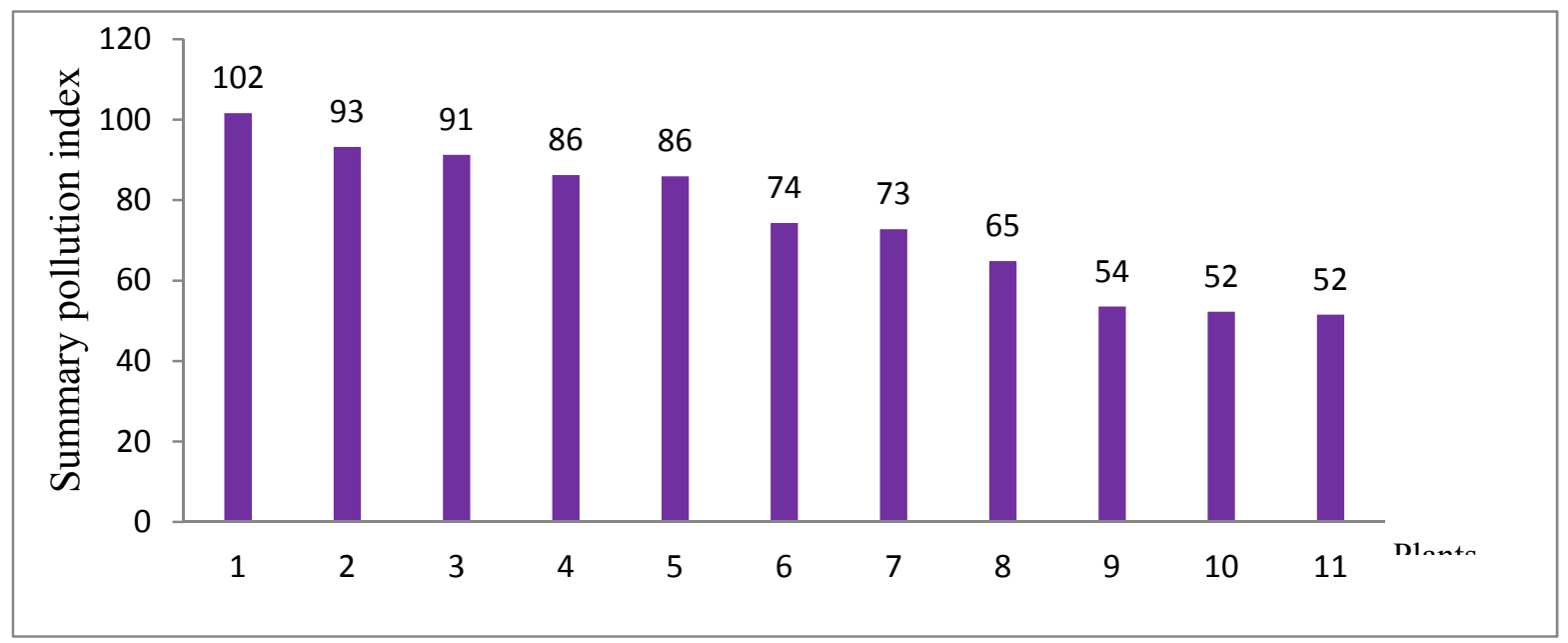

Fig. 3. The total pollution index of urban soils of the studied areas: pollution degree: 1-16 - low; 16-32 - medium; 32-128 - high; more than 128 - is very high. 1 - Ash dump of heat power station; 2 - Borrow pit enterprise; 3 - Concrete products plant; 4 - Construction materials plant; 5 - Concrete components plant-100; 6 - Concrete components plant-40; 7 - Heat power station; 8 -Cement plant; 9 - Concrete plant; 10 - Petrochemical plant; 11 - Artificial stone plant. 


\section{CONCLUSION}

Thus, the level values of all of the studied elements in soils exceeded background concentrations. The observed elements concentrations exceeded the background ones by factor ranging from 1.1 for $\mathrm{Rb}$ (Artificial stone plant) up to 20 for $\mathrm{Br}$ (Borrow pit enterprise) to 28 for Ce (Ash dump of the heat power station). The pollution of all studied areas was estimated as high on the basis of calculated values of the total pollution index. The soil geochemical features are established by elements accompanying production in regions of industrial enterprises locations. The soil composition reflects the specificity of the urban area with various industrial enterprises, due to certain properties of the soil, which constantly accumulates pollutants of emissions from businesses shops and vehicles.

\section{REFERENCES}

[1] P. W. Abrahams, "Soils And Human Health. Eric C. Brevik and Lynn C. Burgess (eds.). PB - CRC Press, Taylor and Francis Group , Boca Raton, Florida, USA. 2013, ISBN 978-1-4398-4454-0 (hardback), 391 pp. £81," Land Degradation \& Development, 27(4), 1308-1308 (2016).

[2] K. A. Ghazaryan, G. A. Gevorgyan, H. S. Movsesyan et al., "The Evaluation of Heavy Metal Pollution Degree in the Soils around the Zangezur Copper and Molybdenum Combine," International Journal of Environmental, Chemical, Ecological, Geological and Geophysical Engineering, 101, 405 - 410 (2015).

[3] N. A. Osipova, L. V. Zhornyak, E. G. Yazikov et al., "XV International Scientific Conference "Chemistry and Chemical Engineering in XXI century" dedicated to Professor L.P. Kulyov Ecological Dangers of Chemical Contamination of Urban Areas Soils: Casestudy of Tomsk," Procedia Chemistry, 10, 508-512 (2014).

[4] V. Alekseenko, and A. Alekseenko, "The abundances of chemical elements in urban soils," Journal of Geochemical Exploration, 147, 245-249 (2014).

[5] S. Islam, K. Ahmed, and H. Al-Mamun, "Distribution of trace elements in different soils and risk assessment: A case study for the urbanized area in Bangladesh," Journal of Geochemical Exploration, 158, 212-222 (2015).

[6] S. Khan, S. Munir, M. Sajjad et al., "Urban park soil contamination by potentially harmful elements and human health risk in Peshawar City, Khyber Pakhtunkhwa, Pakistan," Journal of Geochemical Exploration, 165, 102110 (2016).

[7] L. G. Dao, L. Morrison, and C. S. Zhang, "Spatial variation of urban soil geochemistry in a roadside sports ground in Galway, Ireland," Science of the Total Environment, 408(5), 1076-1084 (2010).

[8] A. Argyraki, and E. Kelepertzis, "Urban soil geochemistry in Athens, Greece: The importance of local geology in controlling the distribution of potentially harmful trace elements," Science of the Total Environment, 482, 366-377 (2014).

[9] A. Lehmann, and K. Stahr, "Nature and significance of anthropogenic urban soils," Journal of Soils and Sediments, 7(4), 247-260 (2007).

[10] S. R. Taylor, "Abundance of chemical elements in the continental crust: a new table," Geochimica et Cosmochimica Acta, 28(8), 1273-1285 (1964).

[11]M. Jiang, G. M. Zeng, C. Zhang et al., "Assessment of Heavy Metal Contamination in the Surrounding Soils and Surface Sediments in Xiawangang River, Qingshuitang District," Plos One, 8(8), (2013).

[12] S. I. Arbuzov, A. V. Volostnov, L. P. Rikhvanov et al., "Geochemistry of radioactive elements (U, Th) in coal and peat of northern Asia (Siberia, Russian Far East, Kazakhstan, and Mongolia)," International Journal of Coal Geology, 86(4), 318-328 (2011).

[13]R. A. Wuana, and F. E. Okieimen, "Heavy Metals in Contaminated Soils: A Review of Sources, Chemistry, Risks and Best Available Strategies for Remediation," ISRN Ecology, 2011, 20 (2011).

[14] A. V. Talovskaya, E. A. Filimonenko, N. A. Osipova et al., "Toxic elements (As, Se, Cd, Hg, Pb) and their mineral and technogenic formations in the snow cover in the vicinity of the industrial enterprises of Tomsk," Xviii International Scientific Symposium in Honour of Academician M. A. Usov: Problems of Geology and Subsurface Development, 21, (2014).

[15] N. A. Osipova, K. A. Filimonenko, A. V. Talovskaya et al., "Geochemical Approach to Human Health Risk Assessment of Inhaled Trace Elements in the Vicinity of Industrial Enterprises in Tomsk, Russia," Human and Ecological Risk Assessment, 21(6), 1664-1685 (2015). 